\title{
Pengaruh Aplikasi Teknologi EGRICS Tipe Cold terhadap Emisi Asap pada Mesin Diesel
}

\author{
Wagino $^{1 *}$, Toto Sugiarto ${ }^{2}$, Dori Yuvenda ${ }^{3}$, Randi Purnama Putra ${ }^{4}$, dan Ahmad Arif \\ ${ }^{12345}$ Jurusan Teknik Otomotif, Fakultas Teknik, Universitas Negeri Padang \\ *e-mail: wagino5520@gmail.com
}

\begin{abstract}
Abstrak - Emisi mesin diesel sangat berbahaya bagi kesahatan manusia adalah nitrogen oksida ( $\mathrm{NO}_{\mathrm{x}}$ ). Emisi NOx dsebabkan oleh temperatur mesin yang sangat tinggi. Salah satu upaya yang efektif untuk menurunkan emisi $\mathrm{NO}_{\mathrm{x}}$ adalah mengembalikan gas buang untuk dibakar kembali yang diistilahkan dengan exhaust gas recirculation (EGR). Namun, dengan metode EGR meningkatkan emisi asap pada mesin diesel. Penelitian ini dilakukan pada mesin diesel empat langkah dengan menggunakan sistem EGR metode injeksi (EGRICS) jenis cold. Parameter penelitian dengan menvariasikan durasi injeksi EGR yang diinjeksikan ke silinder melalui saluran masuk yaitu $15 \mathrm{~ms}, 20 \mathrm{~ms}$ dan $25 \mathrm{~ms}$ dengan putaran 800-2000 rpm dengan interval 200. Hasil penelitian menunjukkan bahwa dengan sistem EGRICS tipe cold pada mesin diesel menghasilkan emisi asap yang paling rendah dengan durasi injeksi sebesar $15 \mathrm{~ms}$ pada setiap putaran mesin. Penggunaan EGRICS jenis cold juga lebih ramah lingkungan dibandingkan dengan EGR jenis hot, hal ini ditandai dengan kenaikan emisi asap pada EGRICS jenis cold lebih rendah daripada EGR jenis hot yaitu sebesar 18,5 \% sehingga dapat menurunkan kadar $\mathrm{NO}_{\mathrm{x}}$ yang terbentuk pada gas buang mesin diesel.
\end{abstract}

Kata Kunci : Mesin diesel, EGRICS, Durasi Injeksi, dan Asap.

\begin{abstract}
Diesel engine emission was very dangerous for human health is nitrogen oxides (NOx). NOx emission was caused by very high engine temperatures. One effective effort to reduce NOx emission was to return the exhaust gas to be burned again, termed exhaust gas recirculation (EGR). However, the EGR method increases smoke emission in diesel engine. This research was conducted on a four-stroke diesel engine using EGR system of method of injection (EGRICS) with cold type. The research parameters by varying the duration of EGR injection injected into the cylinder through the intake manifold was $15 \mathrm{~ms}, 20 \mathrm{~ms}$ and $25 \mathrm{~ms}$ with a rotation of $800-2000 \mathrm{rpm}$ with an interval of 200 . The results showed that the cold type EGRICS system on diesel engine produced the lowest smoke emissions with an injection duration of $15 \mathrm{~ms}$ at each engine speed. The use of cold EGRICS type is also more environmentally friendly compared to hot EGR type, this is indicated by the increase in smoke emissions in cold EGRICS type is lower than hot EGR type that is equal to 18.5\% so that it can reduce NOx levels formed in diesel engine exhaust gases.
\end{abstract}

Keywords : Diesel engine, EGRICS, Injection duration, and Smoke.

This is an open access article distributed under the Creative Commons 4.0 Attribution License

\section{Pendahuluan}

Penggunaan mesin diesel diberbagai sektor seperti industri, pertanian dan transportasi cukup banyak. Hal ini dikarenakan mesin diesel memiliki beberapa keunggulan yaitu daya mesin yang lebih besar, harga bahan bakar yang lebih murah, dan perawatan mesin yang tidak terlalu sulit. Namun demikian, mesin diesel memiliki kelemahan yaitu berkaitan dengan emisi gas buang yang berbahaya terhadap kesehatan manusia dan lingkungan. Emisi gas buang yang dimaksud adalah nitrogen oxide $\left(\mathrm{NO}_{\mathrm{x}}\right)$ dan asap (smoke).

Emisi $\mathrm{NO}_{\mathrm{x}}$ pada mesin diesel lebih banyak diproduksi. Hal ini disebabkan mesin diesel miliki temperatur pembakaran yang tinggi, sehingga Nitrogen $\left(\mathrm{N}_{2}\right)$ dengan mudah beroksidasi dengan 
oksigen $\left(\mathrm{O}_{2}\right)$ membentuk $\mathrm{NO}_{\mathrm{x}}$. Heywood [1] menjelaskan bahwa emisi $\mathrm{NO}_{x}$ lebih banyak diproduksi pada temperatur tinggi terutama pada mesin diesel.

Banyak upaya yang dilakukan oleh peneliti otomotif untuk menurunkan emisi $\mathrm{NO}_{\mathrm{x}}$ seperti menggunakan bahan bakar ganda (dual fuel) [2-7], water injection [8], dan mengembalikan sisa gas pembakaran ke silinder untuk dibakar kembali (exhaust gas recirculation) $[9,10]$ dll. Penelitian ini memfokuskan pada teknologi exhaust gas recirculation (EGR).

EGR adalah metode untuk mengembalikan sebagian gas sisa pembakaran ke silinder untuk di bakar kembali melalui saluran masuk (intake manifold) dengan tujuan untuk mengurangi jumlah kuantitas nitrogen oksida $\left(\mathrm{NO}_{\mathrm{x}}\right)$.

Pengaruh dari mensirkulasikan gas buang ke ruang bakar kemudian dicampur dengan udara segar yang baru masuk ke intake manifold dapat menurunkan temperatur maksimun dan tekanan di daerah flame (pada proses polytropic) sehingga dapat mengurangi reaksi pembentukan NOx. Ini disebabkan beberapa faktor di antaranya adalah [13]

a. Nilai Kapasitas panas (Cp) pada gas buang yang diresirkulasikan lebih tinggi dari nilai $\mathrm{Cp}$ udara segar yang baru masuk ke intake manifold, hal ini menurunkan tekanan dan temperatur pada saat langkah kompresi yang mnyebabkan kecepatan pembakaran (flame speed) berkurang yang berpengaruh pada penurunan puncak tekanan maksimal dan panas yang di lepaskan (heat release rate) pada saat proses pembakaran.

b. Penurunan dari jumlah partikel nitrogen $\left(\mathrm{N}_{2}\right)$ dan oksigen $\left(\mathrm{O}_{2}\right)$ yang masuk ke dalam silinder dikarenakan sebagian udara murni yang masuk ke dalam silinder mesin sudah digantikan oleh gas buang yang masuk sehingga jumlah reaksi antara nitrogen dan oksigen dapat dikurangi pada proses pembakaran.

Jadi proses mensirkulasikan gas buang merupakan salah satu alternatif yang tepat untuk menurunkan partikel $\mathrm{NO}_{\mathrm{x}}$ secara signifikan pada mesin dengan proses pembakaran tekanan konstan. Meskipun demikian pemanfaatan EGR yang berlebihan akan menyebabkan tingginya asap (smoke) sehingga butuh kontrol aliran massa EGR (mass flow rate) yang tepat dari gas buang agar sesuai dengan kondisi mesin.

Indrajaya, [14] melakukan penelitian dengan mengoptimalkan rasio EGR di berbagai pembebanan pada motor diesel dengan metode simulasi CFD dan dia menformulasikan reaksi pembakaran yang terjadi pada mesin diesel dengan berbahan bakar a-heavy oil adalah

$$
\begin{aligned}
& \left.\mathrm{C}_{19} \mathrm{H}_{30}+26,5 \mathrm{O}_{2}+99,64 \mathrm{~N}_{2}\right) \rightarrow 19 \mathrm{CO}_{2}+ \\
& 15 \mathrm{H}_{2} \mathrm{O}+99,64 \mathrm{~N}_{2}
\end{aligned}
$$

Apabila gas buang hasil pembakaran disirkulasikan kembali ke dalam ruang bakar, maka reaksi kimia yang terjadi dapat diformulasikan sebagai berikut:

$$
\begin{aligned}
& \mathrm{C}_{x} \mathrm{H}_{y}+a\left(\mathrm{O}_{2}+\frac{0,79}{0,21} \mathrm{~N}_{2}\right)+b \mathrm{CO}+\mathrm{cH}_{2} \mathrm{O} \rightarrow \\
& d \mathrm{CO}_{2}+e \mathrm{H}_{2} \mathrm{O}+f \mathrm{~N}_{2}
\end{aligned}
$$

\section{A. Jenis sistem EGR}

Berdasarkan temperaturnya sistem EGR dapat dibedakan menjadi dua yaitu

\section{a. Hot EGR}

Sebagian gas buang kendaraan bermotor yang dimasukan kembali ke dalam silinder melalui saluran masuk (intake manifold) tanpa didinginkan terlebih dahulu.

\section{b. Cold EGR}

Sebagian gas buang kendaraan bermotor yang dimasukan kembali ke dalam silinder melalui saluran masuk (intake manifold) yang sebelumnya didinginkan terlebih dahulu menggunakan Cooler. Pendinginan disini hanya maksimal sampai dengan temperature lingkungan saja.

\section{B. Exhaust gas recirculation injection control system (EGRICS)}

EGRICS adalah sebuah metode pemasukan gas buang ke dalam silinder dengan model injeksi yang di atur oleh perangkat kontrol elektronik (ECU) agar gas buang yang di manfaatkan dapat terkontrol sesuai dengan kondisi mesin. Metode ini merupakan pengembangan dari model pemasukan EGR yang konvensional yang hanya menggunakan katup (valve).

Adapun prinsipnya sistem kontrol EGRICS sama halnya dengan sistem kontrol bahan bakar injeksi pada mesin diesel tipe common rail, dimana sistem kontrol ini dilengkapi dengan tiga komponen utama yaitu

a. Sensor ini berfungsi untuk mendeteksi kecepatan putaran mesin dan mendeteksi pergerakan dari langkah piston. Sensor ini dilengkapi dengan sebuah magnet yang bertujuan untuk menghasilkan sinyal berupa tegangan yang terbangkit akibat pemutusan fluq magnet oleh roda gigi yang terpasang pada fly 
wheel yang digunakan sebagai referensi untuk penentuan top satu. Sensor yang digunakan adalah pulser.

b. Prosesor berfungsi sebagai pengolah data kemudian memerintahkan aktuator untuk bekerja, yang bertindak sebagai prosesor adalah ECU.

c. Aktuator adalah bagian komponen yang menerima perintah ECU kemudian menjalankan perintah tersebut sesuai dengan data yang diterimanya. Bagian aktuator dari sistem ini adalah injektor. Injektor berfungsi untuk menginjeksikan gas EGRICS dari tabung penampung ke intake manifold dengan volume gas yang di injeksikan sesuai dengan kebutuhan mesin.

Adapun prinsip kerja dari sistem EGRICS adalah memanfaatkan tegangan yang di bangkitkan pada pulser $(\mathrm{Ne})$. Pada saat roda gila (fly wheel) berputar maka tonjolan (pick up) pada fly wheel akan bersentuhan dengan sensor pulser sehingga sinyal tegangan dibangkitkan dan memberikan informasi ke pada ECU. Kemudian ECU akan memproses data yang telah diperoleh dari pulser kemudian memerintahkan injektor untuk bekerja dengan cara mengaktifkan medan magnet yang ada pada injektor sehingga mengakibatkan injektor menginjeksikan gas EGR yang sudah menunggu pada injector rail. Semakin tinggi putaran maka semakin cepat sinyal yang terbangkitkan pada sensor pulser dan memberikan informasi lebih cepat ke ECU sehingga injektor lebih cepat menginjeksikan gas EGR ke silinder.

\section{Emisi asap (smoke)}

Emisi asap juga disebut dengan partikulat atau jelaga. Partikulat terdiri dari unsur C (karbon) yang masih berupa butiran partikel, dan residu atau kotoran lain dihasilkan oleh pembakaran pada motor diesel. Partikulat sebagian besar dihasilkan oleh adanya residu dalam bahan bakar. Residu tersebut tidak ikut terbakar dalam ruang bakar, tetapi terbuang melalui pipa gas buang. Pembakaran mesin diesel paling banyak menghasilkan partikulat karena di dalam bahan bakar diesel mengandung banyak residu dengan kadar karbon (C) yang banyak. Dengan demikian potensi karbon yang tidak terbakar dengan tuntas lebih banyak dan terbuang melalui pipa gas buang.

Pengendalian emisi $\mathrm{NO}_{x}$ dengan metode EGR pada mesin diesel memberikan dampak yang negatif terhadap emisi asap. Beberapa penelitian menjelaskan bahwa pengaruh penggunaan gas EGR berdapak buruk terhadap emisi asap/partikulat seperti Septiyanto et al.,[15] menjelaskan dalam penelitiannya bahwa pengaruh penggunaan EGR berdampak buruk terhadap emisi asapa dengan kenaikan asap sebesar $24,02 \%$ di bawah beban $25 \%$ dibandingkan dengan asap yang keluar tanpa menggunakan EGR. Hussain et al.,[16] menjelaskan bahwa penggunaan gas buang (EGR) pada mesin diesel menyebabkan peningkatan emisi asap. Hal ini disebabkan karena penurunan kosentrasi oksigen yang masuk ke dalam silinder sehingga pembakaran menjadi tidak tuntas dan meningkatkan produksi partikel.

Beberapa penelitian terdahulu yang berkaitan dengan EGR seperti Peng et al.,[9] menjelaskan bahwa penggunaan EGR memberikan pengaruh yang signifikan terhadap penurunan emisi $\mathrm{NO}_{\mathrm{x}}$, namun dengan penggunaan gas buang yang berlebihan menyebabkan peningkatan emisi asap pada mesin diesel. Khandal et al.,[11] menjelaskan bahwa dengan meningkakan volume gas buang yang masuk ke silinder untuk dibakar kembali dapat menurunkan emisi $\mathrm{NO}_{\mathrm{x}}$ yang signifikan, akan tetapi emisi asap terjadi peningkatan pada mesin diesel. Penurunan emisi $\mathrm{NO}_{\mathrm{x}}$ disebabkan oleh penurunan temperatur pembakaran karena pengaruh dari penurunan puncak tekanan silinder dan laju pelepasan panas. Saleh, [10] menjelaskan bahwa peningkatan persentase EGR pada mesin diesel, menyebabkan penurunan emisi gas buang, namun emisi asap terjadi peningkatan. Hal ini dikarenan penurunan jumlah udara yang masuk sehingga mengurangi kosentrasi okseigen dalam campuran bahan bakardan udara dan penurunan temperature maksimum di dalam silinder. Yasin et al.,[12] menjelaskan bahwa penggunaan EGR dapat menurunkan emisi NOx dan temperature gas buang yang signifikan, namun emisi karbon monoksida (CO), krbon dioksida $\left(\mathrm{CO}_{2}\right)$ dan hidrokarbon (HC) terjadi peningkatan pada mesin diesel.

Berdasarkan penelitian terdahulu tersebut dapat disimpulkan bahwa mengembalikan gas buang ke silinder (EGR) untuk dibakar kembali bersama campuran bahan bakar dan udara dapat menurunkan emisi nitrogen oksida $\left(\mathrm{NO}_{\mathrm{x}}\right)$ pada mesin diesel, namun penggunaan EGR juga berdampak pada kenaikan emisi asap. Dengan demikian diperlukan optimalisasi pada jumlah volume EGR yang digunakan agar tidak berpengaruh besar terhadap kenaikan emisi asap pada mesin diesel.

Penelitian ini menggunakan menggunakan teknologi exhaust gas recirculation with injection 
control system (EGRICS). EGRICS adalah suatu metode yang dilakukan untuk memanfaatkan gas buang hasil pembakaran pada mesin diesel yang dimasukkan kembali ke silinder melalui saluran masuk (intake manifold) dengan model injeksi yang dikontrol secara elektronik menggunakan electronic control unit (ECU).

Pemasukan EGR dengan sistem injeksi merupakan keterbaruan dari penelitian ini, dimana pada penelitian sebelumnya pemasukan EGR dikontrol menggunakan sistem katup (valve) berdasarkan hisapan pada langkah hisap.

Penelitian ini bertujuan untuk mengoptimalkan jumlah penggunaan gas buang dengan metode injeksi (EGRICS) tipe cold melalui variasi durasi injeksi pada mesin diesel, sehingga peningkatan emisi asap tidak terlalu signifikan pada setiap putaran mesin.

\section{Metoda}

Penelitian ini dilakukan dengan menggunakan metode eksperimental. Pengujian dilakukan pada mesin diesel Isuzu Panther 2.3 dengan model pompa injeksi tipe distributor yang dimodifikasi dengan menambahkan sistem EGRICS jenis cold EGR. Sistem kontrol injeksi (injection controller system) dirancang sendiri dengan menggunakan sistem electronic control unit (ECU).

Proses modifikasi mesin dan seluruh rangkaian pengujian dilakukan di Laboratorium Motor Bakar Jurusan Teknik Otomotif Fakultas Teknik Universitas Negeri Padang.

\section{A. Alat Uji}

Alat uji yang akan digunakan dalam penelitian ini adalah sebagai berikut.

\section{a. Mesin uji}

Mesin uji yang digunakan adalah mesin diesel empat langkah, empat silinder dengan sistem bahan bakar tipe distributor. Mesin diesel dimodifikasi dengan menambahkan sistem exhaust gas recirculation (EGR) dengan model injeksi (EGRICS).

Spesifikasi mesin uji yang digunakan pada penelitian ini adalah terlihat pada Tabel 1 di bawah ini.
Table 1. Spesifikasi Mesin

\begin{tabular}{|c|c|}
\hline Spesifikasi & Uraian \\
\hline Merk & Isuzu Panther \\
Type & 2.3 \\
Model & 4 langkah 4 silinder \\
Fuel pump type & Distributor \\
Diplacement & $2300 \mathrm{cc}$ \\
Compression ratio & $20: 1$ \\
Cooling system & Water \\
\hline
\end{tabular}

b. Exhaust gas recirculation injection control system (EGRICS)

Mesin uji dilengkapi dengan sistem EGR dengan model injeksi yang terkontrol secara elektronik (EGRICS). EGRICS adalah suatu sistem yang digunakan untuk meresirkulasikan sebagian gas buang ke dalam silinder dengan cara injeksi sehingga volume dari EGR dapat dikontrol sesuai dengan putaran mesin.

Jenis EGRICS yang digunakana pada penelitian ini adalah adalah jenis Cold EGR yang dilengkapi dengan cooler (pendingin). Tujuan dari pemasangan cooler adalah sebagai pendingin gas buang yang diresirkulasikan kembali ke silinder, supaya panas gas buang tidak merusak sistem injeksi seperti selang dan rail injector.

Pada EGRICS juga dipasang filter sebelum gas buang masuk ke cooler. Tujuannya adalah supaya kotoran sisa pembakaran tidak masuk ke dalam silinder bersamaan dengan gas buang yang diinjeksikan ke silinder melalui saluran masuk (intake manifold).

\section{B. Bahan Bakar}

Bahan bakar yang digunakan dalam penelitian ini adalah bahan bakar solar yang diproduksi oleh PT. Pertamina dengan spesifikasi pada Tabel 2 berikut.

Table 2. Spesifikasi Bahan Bakar Solar

\begin{tabular}{|c|c|}
\hline Propertis bahan bakar & Uraian \\
\hline Low heating value $(\mathrm{MJ} / \mathrm{kg})$ & 42.8 \\
Cetane number & 52.5 \\
Auto-ignition temperature $\left({ }^{\circ} \mathrm{C}\right)$ & 316 \\
A/F Stoichiometric $(\mathrm{kg} / \mathrm{kg})$ & 14.69 \\
Carbon content $(\%)$ & 87 \\
\hline
\end{tabular}

\section{Rancangan Eksperimen.}

Penelitian ini ditetapkan beberapa parameter input dan output pengujian sehingga hasil dari penelitian diharapkan sesuai dengan yang 
diharapkan. Adapun rancangan penelitian tersebut dapat dilihat pada Tabel 3 berikut.

Tabel 3. Rancangan Eksperimen.

\begin{tabular}{|c|c|c|c|c|}
\hline \multicolumn{4}{|c|}{ Parameter Input } & $\begin{array}{c}\text { Parameter } \\
\text { Output }\end{array}$ \\
\hline \multicolumn{2}{|c|}{ Konstan } & \multicolumn{2}{|c|}{ Variasi } & \multirow[b]{2}{*}{ Diukur } \\
\hline $\begin{array}{l}\text { Bahan } \\
\text { bakar }\end{array}$ & $\begin{array}{c}\text { Sistem } \\
\text { EGRICS }\end{array}$ & $\begin{array}{c}\text { Putaran } \\
\text { mesin } \\
(\mathrm{rpm})\end{array}$ & $\begin{array}{c}\text { Durasi } \\
\text { Injeksi } \\
(\mathrm{ms})\end{array}$ & \\
\hline Solar & - & $\begin{array}{c}800-2000 \\
\text { dengan } \\
\text { interval } \\
200\end{array}$ & - & $>$ Asap (\%) \\
\hline Solar & $\begin{array}{l}\text { EGRICS } \\
\text { tipe cold }\end{array}$ & $\begin{array}{c}800-2000 \\
\text { dengan } \\
\text { interval } \\
200\end{array}$ & $\begin{array}{l}>15 \\
>20 \\
>25\end{array}$ & $>$ Asap (\%) \\
\hline
\end{tabular}

\section{Prosedur Pengujian.}

Sebelum melakukan pengujian pada mesin, terlebih dahulu dilakukan modifikasi mesin tersebut dengan menambahkan sistem EGRICS jenis cold EGR. Pengujiian dibagi atas dua kelompok, yaitu kelompok kontrol dengan menggunakan mesin diesel berbahan bakar solar tanpa menggunakan sistem EGRICS dan kelompok uji dengan menggunakan mesin diesel berbahan bakar solar dengan menambahkan sistem EGRICS dengan variasi pengaturan durasi injeksi pada putaran mesin yang berbeda.

Metode yang digunakan untuk mengatur durasi injeksi adalah melakukan mapping menggunakan software VEMSTUNE yang di instal pada komputer. Variasi pengaturan durasi injeksi adalah $15 \mathrm{~ms}, 20 \mathrm{~ms}$ dan $25 \mathrm{~ms}$ pada putaran mesin 800 rpm sampai $2000 \mathrm{rpm}$ dengan interval $200 \mathrm{rpm}$. Pengambilan data emisi asap gas buang dilakukan pada setiap variasi durasi injeksi dan putaran mesin dengan menggunakan alat ukur smoke opacity meter yang dimasukkan di ujung knalpot mesin diesel.

Adapun skema dari penelitian ini dijelaskan pada Gambar 1 di bawah:

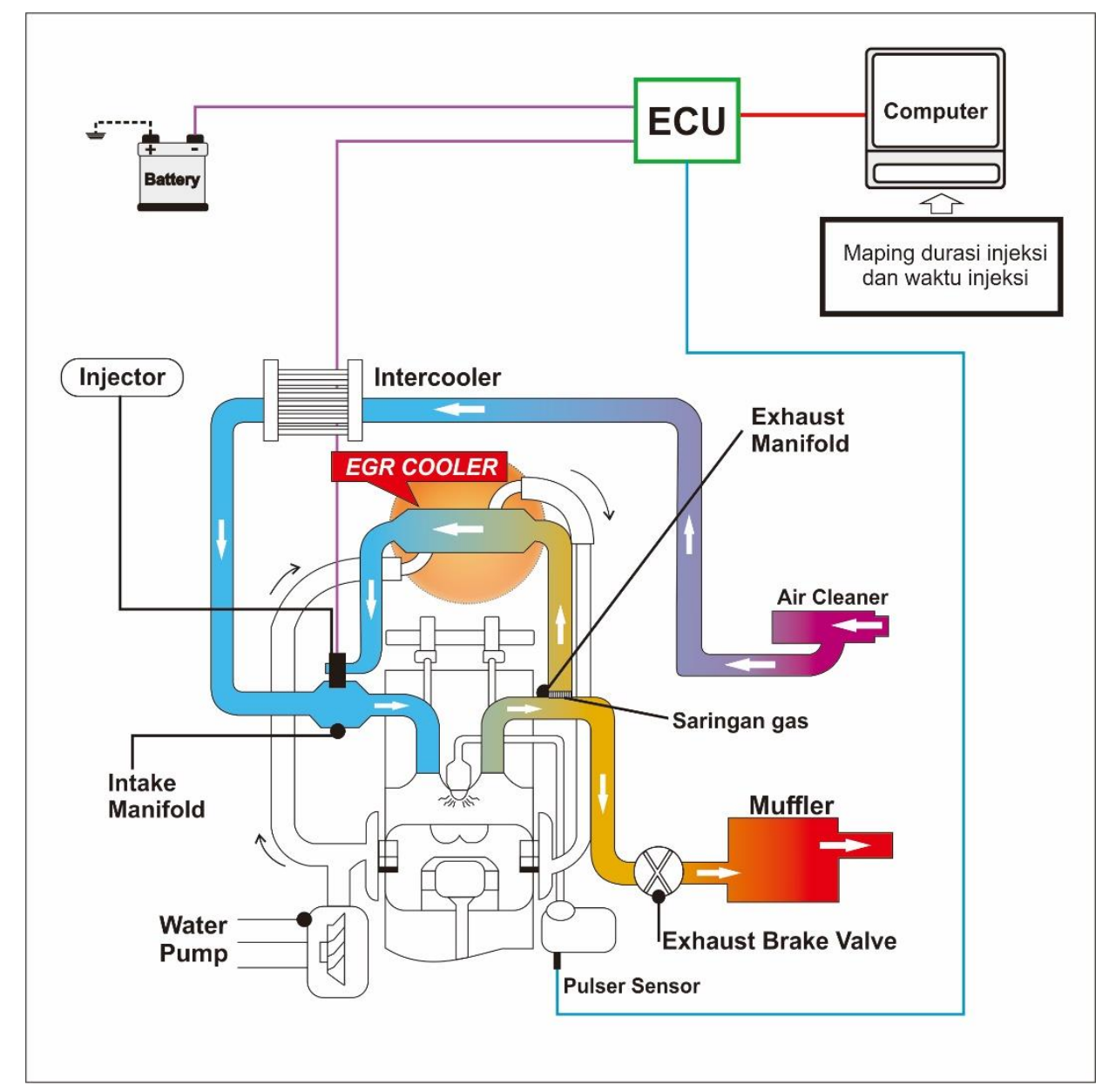

Gambar 1. Skema Penelitian pada Mesin Diesel dengan Sistem EGRICS Tipe Cold. 


\section{HASIL DAN PEMBAHASAN}

Setelah semua proses penelitian dan pengolahan data dilakukan, maka dapat selanjutnya menganalisis hasil yang telah didapatkan.

Gambar 2 menjelaskan pengaruh sistem EGRICS tipe cold terhadap emisi asap dengan memvariasikan pengaturan durasi injeksi pada EGRICS selama $15 \mathrm{~ms}, 20 \mathrm{~ms}$ dan $25 \mathrm{~ms}$ dan putaran mesin selama $800 \mathrm{rpm}$ sampai $2000 \mathrm{rpm}$ dengan interval $200 \mathrm{rpm}$ pada mesin diesel. Sebagai pembanding atau pengontrol, juga dilakukan pengujian emisi asap tanpa menggunakan sistem Cold EGRICS dengan variasi putaran mesin (rpm) yang sama. Emisi asap tanpa EGRICS terlihat lebih rendah dari menggunakan EGRICS di semua variasi durasi injeksi dan putaran mesin. Hal ini disebabkan jumlah udara murni yang lebih banyak (100\%) tanpa menggunakan EGRICS sehingga jumlah kosentrasi oksigen lebih banyak sehingga pembakaran lebih sempuna, dengan demikian produksi partikel/jelaga menjadi lebih rendah.

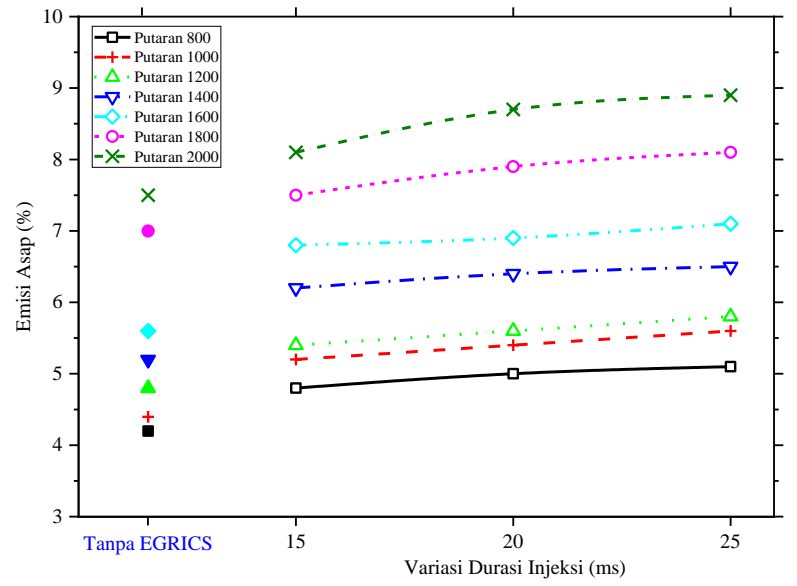

Gambar 2. Pengaruh EGRICS Terhadap Emisi Asap

Grafik 2 menunjukkan bahwa penggunaan EGRICS sangat mempengaruhi tingkat emisi asap mesin diesel. Semakin tinggi durasi injeksi dari EGRICS maka semakin tinggi juga emisi asap, begitu pula dengan putaran mesin (rpm) yang berbanding lurus juga terhadap durasi injeksi dari EGRICS. Kenaikan emisi asap ini disebabkan karena jumlah udara yang masuk ke dalam silinder melalui intake manifold berkurang sehingga kosentrasi $\mathrm{O}_{2}$ menurun, dengan demikian pembakaran menjadi tidak tuntas dan produksi emisi partikel meningkat, seperti yang dijelaskan penelitian sebelumnya $[9,17,18]$ dan juga ketika gas buang di kembalikan ke silinder sehingga tidak hanya molekul $\mathrm{O}_{2}$ dan $\mathrm{N}_{2}$ saja tetapi juga bercampur dengan gas hasil dari sisa pembakaran lainnya seperti $\mathrm{SO}, \mathrm{NO}_{\mathrm{x}}$ dan $\mathrm{CO}$. Akibat pencampuran dari berbagai gas buang tersebut sehingga pembakaran di dalam ruang bakar menjadi tidak sempurna sehingga menyebabkan gas buang/jelaga yang terbentuk tinggi dan meningkatkan emisi asap mesin diesel.

Grafik 2 di atas juga menjelaskan nilai emisi asap terbesar terjadi pada durasi injeksi $25 \mathrm{~ms}$ EGRICS tipe cold dengan putaran mesin $2000 \mathrm{rpm}$ dan emisi asap terendah pada durasi injeksi sebesar $15 \mathrm{~ms}$ dengan putaran mesin $800 \mathrm{rpm}$. Hal ini disebabkan semakin lama durasi injeksi dan semakin tinggi putaran mesinnya maka kebutuhan bahan bakarnya meningkat dan suplai udara untuk pembakaran semakin besar pula, sedangkan dengan menambah durasi injeksi maka jumlah volume gas buang (EGR) yang masuk ke silinder melalui saluran masuk juga akan bertambah banyak. Dengan demikian jumlah udara yang masuk menjadi berkurang sehingga kosentrasi dari oksigen $(\mathrm{O} 2)$ juga ikut menurun, sehingga kualitas pencampuran antara bahan bakar dan udara menjadi tidak sempurna akibatnya pembakaran menjadi tidak tuntas dan produksi partikel/jelaga menjadi tinggi.

Namun demikian, jika dibandingkan dengan beberapa penelitian sebelumnya [14, 15] yang menggunakan sistem hot EGR yang dapat menaikkan emisi asap yang sangat signifikan, maka pada pada penelitian ini menggunakan sistem EGRICS tipe cold hanya mengalami sedikit kenaikan emisi asap dengan rata-rata kenaikan sebesar $18,5 \%$. Hal ini disebabkan karena pada EGRICS tipe cold, sebelum gas buang diinjeksikan kembali ke intake manifold terlebih dahulu didinginkan menggunakan cooler dengan pendingin aliran udara, sehingga mengurangi temperatur gas buang yang masuk ke intake manifold.

Apabila dilihat dari proses pembentukan smoke (asap) dan emisi $\mathrm{NO}_{\mathrm{x}}$ (nitrogen oxide), kedua polutan ini saling bertolak belakang dalam pemunculannya. Emisi asap terbentuk ketika bahan bakar tidak mampu tercampur dengan baik dengan oksigen sehingga reaksi pembakaran tidak sempurna, dalam kondisi seperti ini temperatur pembakaran tidak terlalu tinggi sehingga NOx tidak banyak terbentuk. Oleh karena itu, maka dapat juga disimpulkan bahwa dengan rata-rata kenaikan smoke opacity 18,5\% menyebabkan emisi NOx yang terbentuk juga kecil sehingga memperkecil terjadinya pencemaran udara dan lingkungan. 


\section{KESIMPULAN}

Berdasarkan penelitian yang telah dilakukan, maka dapat disimpulkan bahwa pengaturan durasi injeksi pada sistem EGRICS tipe cold yang optimal adalah sebesar $15 \mathrm{~ms}$ karena menghasilkan emisi asap paling rendah pada setiap putaran mesin. Penggunaan EGRICS jenis cold juga lebih ramah lingkungan dibandingkan dengan EGR jenis hot, hal ini ditandai dengan kenaikan emisi asap menggunakan EGRICS jenis cold lebih rendah dari pada EGR jenis hot yaitu sebesar 18,5\% sehingga dapat menurunkan kadar NOx yang terbentuk pada gas buang mesin diesel. Kemudian cara pemasukan model injeksi menggunakan sistem kontrol ECU lebih baik jika dibandingkan dengan cara pemasukan EGR secara konvensional (katup vakum), hal ini terbukti dengan peningkatan asap yang relatif rendah dan disesuaikan dengan putaran mesin.

\section{Daftar Pustaka}

[1] J. B. Heywood, Internal combustion engine fundamentals. New York : McGraw-Hill, [1988] @1988, 1988.

[2] D. Yuvenda, B. Sudarmanta, and E. Alwi, "Analisis Kekuatan Pegas Pressure Reducer Sebagai Penurunan Tekanan Pada Mesin Duel Fuel," INVOTEK: Jurnal Inovasi Vokasional dan Teknologi, vol. 17, no. 2, pp. 31-38, 2017.

[3] A. Arif, Hidayat, Nuzul, Setiawan, M. Yasep "Pengaruh Pengaturan Waktu Injeksi Dan Durasi Injeksi terhadap Brake Mean Effective Pressure dan Thermal Efficiency pada Mesin Diesel Dual Fuel," INVOTEK: Jurnal Inovasi Vokasional dan Teknologi, vol. 17, no. 2, pp. 67-74, 2017.

[4] J. Jamaludin, D. Yuvenda, and B. Sudarmanta, "The Effect of Addition Electrical Supercharger on Diesel Dual Fuel Engine with Variation of Air Mass Flow Rate to The Engine Performance and Emissions," IPTEK Journal of Proceedings Series, no. 1, pp. 169-175, 2019.

[5] J. da Silva, D. Yuvenda, and B. Sudarmanta, "Effects of Pilot Injection Timing on The Engine Performance of A Diesel Dual Fuel Engine," IPTEK The Journal of Engineering, vol. 5, no. 2, 2019.

[6] M. A. Kurniawan, D. Yuvenda, and B. Sudarmanta, "The Effects CNG Injection Timing on Engine Performance and Emissions of A Diesel Dual Fuel Engine," IPTEK The Journal for Technology and Science vol. 30, no. 2, pp. 64-67, 2019.

[7] D. Yuvenda, B. Sudarmanta, R. P. Putra, M. Martias, and E. Alwi, "Pengaruh Tekanan Injeksi Gas Terhadap Konsumsi Bahan Bakar dan Efisiensi Termal pada Mesin Diesel Dual Fuel," INVOTEK: Jurnal Inovasi Vokasional dan Teknologi, vol. 19, no. 1, pp. 35-42, 2019.

[8] F. Bedford, C. Rutland, P. Dittrich, A. Raab, and F. Wirbeleit, "Effects of Direct Water Injection on DI Diesel Engine Combustion," 2000.

[9] H. Peng, Y. Cui, L. Shi, and K. Deng, "Effects of exhaust gas recirculation (EGR) on combustion and emissions during cold start of direct injection (DI) diesel engine," Energy, vol. 33, no. 3, pp. 471-479, 2008.

[10] H. E. Saleh, "Effect of exhaust gas recirculation on diesel engine nitrogen oxide reduction operating with jojoba methyl ester," Renewable Energy, vol. 34, no. 10, pp. 21782186, 2009.

[11] S. V. Khandal, N. R. Banapurmath, and V. N. Gaitonde, "Effect of exhaust gas recirculation, fuel injection pressure and injection timing on the performance of common rail direct injection engine powered with honge biodiesel (BHO)," Energy, vol. 139, pp. 828 - 841, 2017.

[12] M. H. M. Yasin et al., "Study of a Diesel Engine Performance with Exhaust Gas Recirculation (EGR) System Fuelled with Palm Biodiesel," Energy Procedia, vol. 110, pp. 26-31, 2017.

[13] S. Ramly, B.A, "Design of Exhaust Gas Recirculation System (EGR) for Diesel Engine," Thesis, Mechanical Engineering, Universiti Malaysia Pahang, 2012.

[14] I. Gerianto, Ariana, I. Made, Umam, Khairul "Optimalisasi Rasio Exhaust Recirculation (Egr) pada Berbagai Pembebanan Motor Diesel Dengan Pemodelan Simulasi," 23/04/2010 Teknik Sistem Perkapalan, Institut Teknologi Sepuluh Nopember, Perpustakaan ITS, 2010.

[15] A. Septiyanto, Maulana, Sonika, Nugroho, Agus, Sudiyono "Pengaruh Exhaust Gas Recirculation (Egr) terhadap Performa dan Emisi Jelaga Mesin Diesel Direct Injection," Jurnal Sains dan Teknologi (Sainteknol), vol. 15, no. 2, pp. 129-136, 2017.

[16] J. Hussain, K. Palaniradja, N. Alagumurthi, and R. Manimaran, "RETRACTED: Effect of Exhaust Gas Recirculation (EGR) on Performance and Emission characteristics of a Three Cylinder Direct Injection Compression Ignition Engine," Alexandria Engineering Journal, vol. 51, no. 4, pp. 241-247, 2012.

[17] B. Rajesh kumar and S. Saravanan, "Effect of exhaust gas recirculation (EGR) on performance and emissions of a constant speed DI diesel engine fueled with pentanol/diesel blends," Fuel, vol. 160, pp. 217-226, 2015/11/15/2015.

[18] S. V. Khandal, N. R. Banapurmath, and V. N. Gaitonde, "Effect of exhaust gas recirculation, fuel injection pressure and injection timing on 
the performance of common rail direct injection engine powered with honge biodiesel (BHO)," Energy, vol. 139, pp. 828-841, 2017.

\section{Biodata Penulis}

Wagino, merupakan salahsatu staf pengajar di Jurusan Teknik Otomotif Universitas Negeri Padang. Menyelesaikan gelar S1 dan S2 dari Universitas Negeri Padang. Memiliki ketertarikan riset di bidang Teknik Otomotif dan Pendidikan vokasional.

Toto Sugiarto, merupakan staf pengajar di Jurusan Teknik Otomotif Universitas Negeri Padang dengan ketertarikan riset di bidang Teknik Otomotif dan Pendidikan Vokasional. Menyelesaikan Pendidikan S1 di Universitas Negeri Padang dan Pendidikan S2 di Universitas Andalas.

Dori Yuvenda, lahir di Bukittinggi, 1 Nopember 1988. Sarjana Pendidikan Teknik Otomotif dari Universitas Negeri Padang, lulus 2013. Tahun 2015 memperoleh gelar Magister Teknik Mesin pada Departemen Teknik Mesin Institut Teknologi Sepuluh Nopember, Surabaya. Staf pengajar pada Jurusan Teknik Otomotif FT UNP sejak tahun 2015 - sekarang.

Randi Purnama Putra, lahir di Padang, 28 Juli 1988. Sarjana Pendidikan Teknik Otomotif dari Universitas Negeri Padang, lulus 2011. Tahun 2013 memperoleh gelar Magister Teknik Mesin pada Departemen Teknik Mesin Institut Teknologi Sepuluh Nopember, Surabaya. Staf pengajar pada Jurusan Teknik Otomotif FT UNP sejak tahun 2013 - sekarang.

Ahmad Arif, lahir di Padang Panjang, 27 Februari 1989. Sarjana Pendidikan di Jurusan Teknik Otomotif FT UNP 2012. Tahun 2015 memperoleh gelar Magister Teknik di Program Studi Rekayasa Konversi Energi Jurusan Teknik Mesin Program Pascasarjana ITS Surabaya. Staf pengajar di Jurusan Teknik Otomotif FT UNP sejak tahun 2015 - sekarang. 